\title{
Complex Correctional Institutions at the Present Stage of Reforming the Penal Enforcement System of the Russian Federation
}

\author{
VYACHESLAV E. YUZHANIN \\ Law Institute of the Ryazan State University named for S.A. Yesenin, Ryazan, \\ Russian Federation \\ ORCID: https://orcid.org/0000-0003-3123-1293, e-mail: yuzhanin1950@mail.ru \\ DMITRII V. GORBAN' \\ Saint Petersburg University of the Federal Penitentiary Service of Russia, Saint \\ Petersburg, Russian Federation \\ ORCID: https://orcid.org/0000-0002-9442-7712, e-mail: dimas8807@mail.ru
}

\begin{abstract}
Introduction: the article is devoted to the creation of correctional institutions of combined type with regard to the current penal enforcement legislation and the Concept for the development of the penal enforcement system of the Russian Federation up to 2030. The foundation of correctional institutions of this type corresponds to the modern penal enforcement policy of the Russian Federation, but requires scientific study. The relevance of the presented article is also determined by modern trends in penitentiary science and practice. Purpose: on the basis of generalization and analysis of official statistical data, theoretical and scientific sources, findings and approaches of scientists-penitentiaries, to comprehensively reveal the prospects for establishing institutions of combined type at the current stage of the RF penal enforcement system development. Methods: the dialectical method of scientific cognition was used when writing a scientific article. The following scientific methods of cognition were also applied: comparative law, induction, deduction, analysis, synthesis, and statistical. Results: in the course of the study and based on its results, the authors developed a theoretical model of a complex correctional institution (institution of combined type), which includes separate areas proposed and scientifically justified by the authors. Each area of the combined type institution selected by the authors is described separately and in detail. The theoretical model of a complex correctional institution (institution of combined type) corresponds to the provisions of the current legislation, as well as the prospects for its development up to 2030, and also widens and complements them. Conclusions: in order to capture correctional facilities of a combined type in the RF penal enforcement legislation, it is proposed to enshrine the theoretical model of a complex correctional institution proposed by the authors in the corresponding articles.

Ke y w o r d s : correctional facility, multi-regime, reforming, concept, convict, complex institution, hybrid institution.

12.00.08 - Criminal law and criminology; panel enforcement law.

F or c itation: Yuzhanin V.E., Gorban' D.V. Complex correctional facilities at the present stage of reforming the penal enforcement system of the Russian Federation, Penitentiary Science, 2021, vol. 15, no. 4(56), pp. 854-859. DOI 10.46741/2686-97642021-15-4-854-859.
\end{abstract}

\section{Introduction}

Reforming the RF penal enforcement system at the present stage of its development involves a number of promising modernization areas, including betterment of the mechanism of serving a custodial sentence by creating complex correctional institutions (correctional institutions of combined type).

As of September 1, 2021, about 470 thousand people were held in institutions of the penal enforcement system, about 360 thousand people - in correctional facilities [5]. 
The Federal Penitentiary Service of Russia records a downward trend in the number of adult convicts kept in correctional facilities (CF) of the penitentiary system for the 1st half of 2021 . The reduction in the number of persons sentenced to imprisonment also implies a decrease in the number of correctional institutions themselves [8].

In this regard, one basic correctional facility can combine several types of regimes, as well as in the future execute several types of criminal penalties (for example, imprisonment for a certain period and life imprisonment).

\section{Results}

The concept of multi-regime (hybridity) of correctional institutions is actively discussed in the scientific literature. Scientists consider the trend of enlargement of correctional institutions as "hybridity" and "multi-regime". R.Z. Useev mentions interspecific and intraspecific hybridity [10, p. 32].

A "hybrid" correctional institution is to combine various types of correctional facilities, and a "multi-regime" one - several different types of regimes for serving criminal sentences [15, p. 105].

V.A. Utkin in this context speaks of a certain "polarization" of correctional institutions. We share his position on the special role of strict regime colonies, on the basis of which it is planned to create combined type institutions [14, p. 101].

According to official statistics, as of January 1,2021 , the correctional system was represented by 816 institutions, particularly: 186 facilities were pre-trial detention centers; 75 - remand prisons; 8 - prisons; 528 correctional facilities (169 of general regime; 228 - strict regime; 37 special regime, including for those sentenced to life imprisonment.

Thus, today strict regime correctional facilities comprise about 43 percent of the total number of all correctional colonies, and about 28 percent of the total number of correctional institutions. In our opinion, when creating institutions of combined type, it is necessary to use capacities of all correctional facilities of all types of regime available in the penal enforcement system of the Russian Federation.

Law enforcement practice tries to fully use capacities of such correctional facilities. So, the first correctional institution of combined type is supposed to be established on a pilot basis at the premises of the correctional institutions of the Federal Penitentiary Service of Russia in the Kaluga Oblast. It will include all types of regimes, production, a medical facility, a child care home, as well as a campus for employees [9].

We propose to call hybrid, multi-regime correctional institutions as complex [1, p. 39]. First, this term combines all kinds of multi-regime and hybridity, which are discussed in scientific literature. Second, it is more consistent with the position of the legislator and the law enforcement officer, according to which this type of institution is referred to as institutions of combined type.

According to the RF Government Decree of April 29, 2021 No. 1138-r "On approval of the Concept for development of the RF penal enforcement system for the period up to 2030", elaboration and implementation of the project to create an institution of combined type (sections 6 and 7 ) is one of the critical directions for enhancement and development of the penal enforcement system.

The key principle for creating institutions of combined type are:

- concentration of several correctional institutions and pre-trial detention centers in a single center;

- modernization and unification of existing technologies;

- focus on a client-centric approach, etc.

The development and realization of the project to set up a combined type facility is expected to be completed by 2024 .

Our stance on the creation of complex institutions is supported by other penitentiary scientists.

So, I.N. Korobova and D.A. Seredokhin state that the transition to complex correctional institutions at the premises of correctional facilities is the most adequate, since it involves not a global restructuring of existing institutions, but only a rational use of territories and buildings of correctional facilities with small changes compared to their restructuring into prisons [3;4].

The trend for complexity of correctional institutions was laid down in the Penal Enforcement Code of the Russian Federation in 2001 [13, p. 105]. Since that moment, it has been amended, providing for the functioning of several types of isolated areas with different types of regime and different types of correctional institutions at the premises of one correctional facility. Nowadays, this trend is being implemented under the current the penal enforcement system of the Russian Federation.

It should be noted that the issue under study does not contradict international regulatory le- 
gal documents. Thus, paragraph 93 of the 2015 Standard minimum rules for the treatment of prisoners states that work with different categories of prisoners should be carried out in different departments of the same prison institution.

Thus, as V.A. Utkin emphasizes, international acts fully admit and even assume the polystructure and associated multi-regime of penitentiary institutions [11, 12].

Positive experience of some foreign countries testifies to the application of the abovementioned norm of the international document and the creation of areas with different types of regimes and various types of correctional institutions at the premises of prisons.

This positive experience is widely used in Germany, Finland, Austria and other foreign countries [21].

Conclusions.

The author's theoretical model of a complex correctional institution (institution of combined type) is worked out on the basis of analyzed scientific literature, official statistics of the Federal Penitentiary Service of Russia, and trends in the modern penal enforcement policy and law enforcement practice.

The following areas are included in this model:

1) adaptation- for newly arrived convicts [6, p. 62];

2) intensive treatment - for convicts transferred from the adaptation area;

3) cell detention - for violators of the established order of serving a sentence, as well as realization of the convicts' right to safety in the cases provided for by law;

4) medical - for the provision of medical assistance to convicts and the realization of their respective rights in this direction;

5) remand prison - for detention of persons who have been assigned a preventive measure in the form of detention;

6) correctional center - for execution of criminal punishment in the form of forced labor;

7) social adaptation - for implementation of the relevant task of the penal enforcement legislation, as well as pre-release treatment of convicts.

We will consider the purpose of each area separately.

Adaptation area. It is intended to contain convicts who have arrived at a correctional institution, assist them to adapt to the conditions for serving their sentence. According to Article 79 of the Panel Enforcement Code of the Russian Federation, new arrivals are held in a quarantine department for up to 15 days, where are they under usual conditions of serving their sentence. In fact, this department may be called medical, not adaptation. There convicts undergo a full medical examination, visit orientation activities, conducted by representatives of all departments and services of the correctional facility. Then they are transferred to appropriate detachments, according to the decision of the correctional facility administration commission.

In practice, the personality of a convicted person is not studied by specialists, and he/ she does not have time to adapt in such a short period (15 days). We believe a 1.5-3-month adaptation period (depending on the category of convicts) is required. The measures to include a convict into the life of the institution should be conducted by a psychologist, who eventually, having studied the personality of a convicted person, can draw up a program for his/her rehabilitation.

Russia has certain experience of adaptation detachments in the correctional facilities (in the Chelyabinsk, Omsk oblasts, the Republic of Mordovia, etc.) and it shows that after longterm adaptation convicts tend to violate the regime much less and take the path of correction faster. This conclusion is also confirmed in the dissertation research of E.E. Novikov [7, p. 20].

Currently, the problem of ensuring the rights of convicts and their personal safety becomes urgent. After studying the personality of an offender and determining a classification group according to the degree of danger, it is possible to send him for further serving of his sentence either to normal conditions, or strict conditions, or a cell detention area. He may be placed on the register for preventive purposes.

The idea of separate detention of persons seeking correction from convicts who are eager to harass other convicts, disobey the administration, and continue criminal activity can be implemented at an early stage, while they are in the adaptation area. All this should contribute to the creation of favorable conditions for the resocialization of most convicts in places of deprivation of liberty [18, p. 148].

Intensive treatment area. It is the key area in the correctional facility. It should contain convicts serving their sentences under normal or light conditions. The initial stage of serving the sentence is replaced by the main stage, when convicts are transferred from the adaptation area to that of intensive treatment. Most offenders are kept under normal conditions. 
In correctional colonies, as of January 1 , 2021 , about $79 \%$ of convicts served their sentences under normal conditions, $12 \%$ - under light conditions, and 9\% - under strict ones [5]

In our opinion, light conditions should prevail in the correctional facilities. The fact is that under normal conditions, up to $80 \%$ of convicts are characterized positively or neutrally. If they do not have penalties, then according to the current legislation they can be transferred to light conditions after serving the prescribed period.

Normal conditions should be perceived as part of the initial stage of serving a sentence, which has the main task of adapting convicts to the life in the correctional facility and testing them for subsequent behavior in the institution. According to the current legislation, in case of absence of penalties, they can be transferred to light conditions in colonies of general, strict and special regimes after 6, 9, and 12 months, respectively (Part 2 of Article 120, Part 2 of Article 122, Part 2 of Article 124 of the Penal Enforcement Code of the Russian Federation). But for some reason, the administration does not seek to transfer them to less-strict conditions. In addition, convicts are usually kept together in light and normal conditions. In fact, besides additional spending of money and an increased number of parcels and visits, they do not experience changes in the conditions of serving their sentence.

In modern conditions, the dominant idea is the idea of separate detention of persons seeking correction. $67 \%$ of the CF employees we surveyed supported this idea. We are referring to the category of persons who have achieved a high level of correction, but have not served the prescribed period for parole.

A separate section of individual cell detention of convicts with a high level of correction should be allocated in the intensive treatment area. This regime can be called preferential and those convicts can be transferred to it, who have proved their correction under light conditions and have concluded a kind of compromise agreement with the CF administration, providing for mutual rights and obligations [20, p. 10].

We believe that a regime of convicts' behavior self-regulation should be established on preferential terms, which excludes coercion as much as possible. The administration does not use a permissive-coercive method for regulating convicts' behavior, but provides them with assistance. Preferential treatment should stimulate the behavior of convicts who are in less- strict conditions [17, p. 142]. It fulfils the function of preparing convicts to conditional early release.

The cell detention area should have premises operating as prison (part 2 of Article 74 of the Panel Enforcement Code of the Russian Federation), as well as ward-type rooms and punishments cells. There is no need to create a separate section functioning as prison, since the conditions for convicts in them are almost similar to those in ward-type rooms. As a rule, malicious regime violators are held there. Single-space ward-type rooms are equivalent to prisons and ward-type rooms in terms of restrictive conditions (Article 118 of the Panel Enforcement Code of the Russian Federation). In addition, malicious regime violators may be assigned strict conditions for serving their sentences in separate locked rooms (paragraph 22 of the Internal regulations of the correctional institution). In general, it turns out that this category of persons can be kept, according to the institution head, in ward-type rooms, singlespace ward-type rooms, prison, or strict conditions.

The Federal Law No. 569-FZ of December 27, 2018 defines the prison regime for terrorismrelated crimes, crimes against statesmen, law enforcement officers, sabotage, as well as for other particularly serious crimes encroaching on state interests (part 2 and part 2-1 of Article 58 of the RF Criminal Code). In our opinion, this category of persons should be sent to separate independently functioning prisons. They should also contain persons committed a particularly serious crime with a sentence of more than 5 years and particularly dangerous recidivists.

We propose to abolish single-space wardtype rooms, as a disciplinary measure, replace them with prisons that can function in the correctional facility according to part 2 of Article 74 of the Penal Enforcement Code of the Russian Federation. These prisons should serve to a greater extent as a security measure: they are for persons having the highest criminal hierarchy status (Article 210-1 of the Criminal Code of the Russian Federation), persons who manifest extremist aspirations during their detention in the correctional facility, as well as persons recognized as malicious regime violators while serving their sentence in this CF if all corrective actions turn out to be unsuccessful, including after their stay in the punishment cell, ward-type room and strict conditions. Ward-type rooms, as a disciplinary measure, should keep convicts repeatedly violating the regime during and af- 
ter their detention in strict conditions of serving their sentence. In general, for malicious regime violators the following chain of corrective actions should be formed within one institution: strict conditions - ward-type room - prison. Strict conditions are milder, inmates do not live in cells, but in locked rooms of the dormitories. When transferred to a ward-type room, they live in cells, but for up to 6 months. When they are subsequently transferred to prison, they are also kept in cells, but for longer periods - up to 3 years. With continuous illegal behavior, the conditions of disciplinary action are gradually tightened. Moreover, the penal enforcement legislation should grant to the CF head the right to transfer inmates to prison within the institution with the consent of the public monitoring commission without the court decision.

Thus, the cell detention area should serve as security and disciplinary measures.

As we have already noticed, the section of strict conditions of serving a sentence is intended for persons recognized as malicious regime violators (for example, parts 3 and 4 of Article 120 of the Penal Enforcement Code of the Russian Federation). Strict conditions should be the initial measure, according to which the conditions of serving a sentence are changed for the worse for malicious regime violators within the correctional facility. According to paragraph 22 of the Internal regulations of the correctional institution, they are kept in premises equipped in accordance with the norms of current legislation.

These locked premises should be located in separate isolated areas. The specifics in serving a sentence there is restrictive conditions associated with isolation of convicts in locked rooms. They are only allowed to leave these premises in the cases provided for by law. Therefore, this unit functions autonomously and should be isolated from others.

Medical area. It is provided for convicts held in a penal institution for their medical and sanitary-hygienic services (part 2 of Article 101 of the Penal Enforcement Code of the Russian Federation). Medical treatment and preventive care facilities may be set up as part of correctional institutions, and child care homes, maternity wards and dairy kitchens - as part of female colonies

The medical and sanitary part is located in a separate isolated area, walled off from another territory by a solid filling fence. The access of convicts to it is limited, special rules for visiting it by sick convicts are established.

Remand prison. It is intended for detention of persons who have been assigned a preventive measure in the form of detention.

Correctional center. It is intended for the execution of criminal punishment in the form of forced labor.

The social adaptation area is designed for convicts who are preparing for release after serving the full sentence. For them, this is the final stage of imprisonment.

There the CF administration should carry out a set of measures related to training for skills development necessary for employment and resettlement after release and promoting relationships of the convicted with their family and relatives, etc.

No doubt, to encourage full-fledged social adaptation of inmates, it is necessary to create conditions of semi-freedom for them. According to some studies, offenders experiencing similar conditions have a higher adaptation level [16, p. 163]. This is especially true for persons who have served long terms of imprisonment.

It is important for the convicts being released to focus on adaptation, for this they should be united in one group and isolated from other convicts in a separate section.

Part 3 of Article 121 of the Penal Enforcement Code of the Russian Federation provides for convicts held under light conditions in general regime colonies to live and work outside the CF under the control of the administration. It promotes offenders' successful socialization. But why is it appropriate only for convicts held under light conditions and only in general regime colonies? In this case, the legislator is guided not by the expediency, but by the idea that one can trust only those who have shown a desire for correction and who are sentenced for the first time. Why is it impossible to expand these semi-free conditions of serving a sentence for 6 months before release to all categories of convicts and all types of colony regimes, with the exception of those who, according to operational data, pose a danger to society? These conditions may be called open, as stipulated by the legislation of some foreign countries.

It is reasonable to ensure appropriate levels of control and supervision of convicts held before release in the social adaptation area in correctional facilities of each type of regime [2; 19]. 


\section{REFERENCES}

1. Gorban' D.V. "Complex" correctional institutions in the penitentiary system of Russia at the present stage of its reforming. Aktual'nye voprosy bor'by s prestupleniyami=Topical Issues of Combating Crimes, 2015, no. 1, pp. 38-43. (In Russ.).

2. Gorban' D.V., Yuzhanin V.E. Prozhivanie osuzhdennykh za predelami ispravitel'nykh uchrezhdenii kak element progressivnoi sistemy otbyvaniya lisheniya svobody: problemy teorii i praktiki: monografiya [Living of convicts outside correctional institutions as an element of a progressive system of serving imprisonment: problems of theory and practice: monograph]. Tomsk: Izd-vo Tomskogo politekhnicheskogo universiteta, 2016. $191 \mathrm{p}$.

3. Korobova I.N. On the issue of creating integrated correctional institutions in the Russian Federation. Vestnik Kuzbasskogo instituta=Bulletin of the Kuzbass Institute, 2020, vol. 43, no. 2, pp. 58-63. (In Russ.).

4. Korobova I.N., Seredokhin D.A. Reforming correctional colonies as a basis for changing the correctional system. In: Ugolovno-ispolnitel'naya sistema na sovremennom etape i perspektivy ee razvitiya: Sbornik tezisov vystuplenii i dokladov uchastnikov Mezhdunarodnoi nauchno-prakticheskoi konferentsii [The penal enforcement system at the present stage and prospects for its development: collection of abstracts of speeches and reports of participants of the International researchto-practice conference]. Ryazan: Akademiya FSIN Rossii, 2020. Pp. 105-111. (In Russ.).

5. Brief description of the penal enforcement system of the Russian Federation. Federal'naya sluzhba ispolnenii nakazanii: ofitsial'nyi sait [Federal Penitentiary Service of Russia: official website]. Available at: https://fsin.gov.ru/structure/inspector/ iao/statistika/Kratkaya\%20har-ka\%20UIS/ (accessed September 14, 2021).

6. Novikov E.E. Adaptation of convicts in quarantine in prison. Vestnik Kuzbasskogo instituta=Bulletin of the Kuzbass Institute, 2015, vol. 25, no. 4, pp. 62-66. (In Russ.).

7. Novikov E.E. Pravovoe regulirovanie napravleniya osuzhdennykh $v$ ispravitel'nye uchrezhdeniya, ikh priema $i$ razmeshcheniya: avtoreferat na soiskanie uchenoi stepeni kandidata yuridicheskikh nauk [Legal regulation of the transfer of convicts to correctional institutions, their reception and placement: Candidate of Sciences (Law) dissertation abstract]. Ryazan, 2011. 24 p.

8. Overview of information on the activities of the Federal Penitentiary Service of Russia for the 1st half of 2021. Federal'naya sluzhba ispolnenii nakazanii: ofitsial'nyi sait [Federal Penitentiary Service of Russia: official website]. Available at: https:// fsin.gov.ru/statistics/obzor-informatsii-o-deyatelnosti-fsin-rossii-za-i-polugodie-2021-goda.php, svobodnyi. (accessed September 14, 2021).

9. The first multi-institution of the Federal Penitentiary Service may appear in the region closest to Moscow. Rossiiskaya gazeta: ofitsial'nyi sait [Russian newspaper: official website]. Available at: https://rg.ru/2021/03/12/reg-cfo/pervoe-multiuchrezhdeniefsin-mozhet-poiavitsia-v-blizhajshem-k-moskve-regione.html (In Russ.). (Accessed September 28, 2021).

10. Useev R.Z. The hybridity of places of deprivation of liberty in the view of security of the criminal-executive system. Vedomosti ugolovno-ispolnitel'noi sistemy=Vedomosti of the Penal Enforcement System, 2017, vol. 179, no. 4, pp. 30-35. (In Russ.).

11. Utkin V.A. Hybrid correctional facilities and international standards. Ugolovno-ispolnitel'noe pravo=Penal Law, 2014, vol. 18, no. 2, pp. 7-11. (In Russ.).

12. Utkin V.A. Minimal'nye standartnye pravila organizatsii ob"edinennykh natsii i smena ugolovno-ispolnitel'nykh paradigm. Mezhdunarodnyi penitentsiarnyi zhurnal=International Penitentiary Journal, 2016, no. 1, pp. 67-70. (In Russ.).

13. Utkin V.A. Assignment of punishment and penal system. Vestnik Kuzbasskogo instituta=Bulletin of the Kuzbass Institute, 2016, vol. 29, no. 4, pp. 104-109. (In Russ.).

14. Utkin V.A. New concept of development of penal system: bases and principles Vestnik Kuzbasskogo instituta=Bulletin of the Kuzbass Institute, 2018, vol. 37, no. 4, pp. 99-103. (In Russ.).

15. Utkin V.A., Kiselev M.V., Savushkin S.M. "Hybrid" and "multi-regime" penitentiary institutions: advantages and risks. Vestnik Tomskogo gosudarstvennogo universiteta. Pravo=Tomsk State University Journal of Law, 2018, no. 29, p. 103113. (In Russ.).

16. Tsibul'skii V.V. Sotsial'no-pedagogicheskaya deyatel'nost' sotsial'nogo rabotnika s osuzhdennymi, pol'zuyushchimisya pravom peredvizheniya bez konvoya za predelami ispravitel'nykh uchrezhdenii: dissertatsiya na soiskanie uchenoi stepeni kandidata pedagogicheskikh nauk [Social and pedagogical activity of a social worker with convicts using the right to travel without escort outside correctional institutions: Candidate of Sciences (Pedagogy) dissertation]. Moscow, 2003. 190 p.

17. Yuzhanin V.E. Characteristics of the main stage of punishment serving by convicts in correctional institutions. Vestnik Kuzbasskogo instituta=Bulletin of the Kuzbass Institute, 2020, vol. 42, no. 1, pp. 141-143. (In Russ.).

18. Yuzhanin V.E., Gorban' D.V. Initial and final stages of serving imprisonment: problems of conceptual definition. Chelovek: prestuplenie i nakazanie=Man: Crime and Punishment, 2018, no. 2, pp. 148-150. (In Russ.).

19. Yuzhanin V.E., Gorban' D.V. Institution of preparing convicts for release in the progressive system of serving the sentence of imprisonment. Psikhopedagogika v pravookhranitel'nykh organakh=Psychopedagogy in Law Enforcement, 2020, vol. 25, no. 3 (82), pp. 338-344. (In Russ.).

20. Yuzhanin V.E., Smirnov I.A. Poetapnaya resotsializatsiya polozhitel'no kharakterizuyushchikhsya osuzhdennykh: prakticheskie rekomendatsii [Step-by-step resocialization of positively characterized convicts: practical recommendations]. Ryazan: Akademiya FSIN Rossii, 2020. 34 p.

21. Timofeeva E.A. Foreign prison experience resocialization of prisoners. SHS Web of Conferences, 2019, vol. 62, pp. 1-4. DOI: https://doi.org/10.1051/shsconf/20196212004.

\section{INFORMATION ABOUT THE AUTHORS}

VYACHESLAV E. YUZHANIN - Doctor of Sciences (Law), Professor, Professor of the Department of Criminal Law and Criminology of the Ryazan State University named for S.A. Yesenin, Ryazan, Russian Federation, ORCID 0000 0003-31231293, e-mail: yuzhanin1950@mail.ru

DMITRII V. GORBAN' - Candidate of Sciences (Law), Associate Professor of the Department for Punishment Execution Organization of the Faculty of Law of the Saint Petersburg University of the Federal Penitentiary Service of Russia, Saint Petersburg, Russian Federation, ORCID 0000-0002-9442-7712, e-mail: dimas8807@mail.ru 